\begin{tabular}{cc|c}
\hline Tar. Bil. Der. & Journal of Agricultural Sciences \\
& $\begin{array}{c}\text { Dergi web sayfası: } \\
\text { www.agri.ankara.edu.tr/dergi }\end{array}$ & Journal homepage: \\
& www.agri.ankara.edu.tr/journal
\end{tabular}

\title{
Essential Plant Nutrients and Heavy Metals Concentrations of Some Medicinal and Aromatic Plants
}

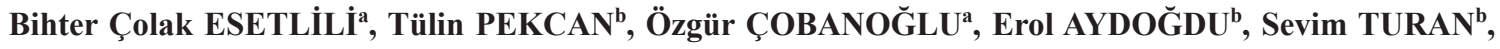 \\ Dilek ANAÇa \\ ${ }^{a}$ Ege University, Faculty of Agriculture, Department of Soil Science \& Plant Nutrition, Bornova, 35100, İzmir, TURKEY \\ ${ }^{b}$ Station of Olive Research, Üniversite Caddesi, No:43, 35100, Bornova, İmir, TURKEY
}

\section{ARTICLE INFO}

Research Article DOI: 10.1501/Tarimbil_0000001283

Corresponding Author: Bihter Çolak ESETLİİ,E-mail: bihtercolak@gmail.com, Tel: +90 (232) 3111515

Received: 24 August 2013, Received in Revised Form: 24 February 2014, Accepted: 02 March 2014

\section{ABSTRACT \\ In Turkey, the majority of medicinal plants at the selling points are wildly harvested. Therefore, no control exists during their growth and development. The public awareness on effects of environmental pollution in this regard especially with respect to heavy metals in the herbs is increasing. With this objective, medicinal and aromatic plants were collected from herbalists in different, densely populated districts of Izmir Municipality. The concentrations of some essential plant nutrient elements (N, P, K, Ca, Mg, Na, Fe, Mn, Cu, Zn, B, and Mo) and toxic heavy metals ( $\mathrm{Co}, \mathrm{Cd}, \mathrm{Cr}, \mathrm{Ni}$, and $\mathrm{Pb}$ ) and $\mathrm{Al}$ were measured. Results showed that herbs are rich in the investigated mineral elements; however, some of the heavy metals are found to be at concentrations above the reported critical levels. \\ Keywords: Medicinal and aromatic plants; Heavy metal; Essential plant nutrients; Macro nutrients; Micro nutrients \\ Bazı Tıbbi ve Aromatik Bitkilerin Ağır Metal ve Temel Besin Elementi İçerikleri}

\section{ESER BILGISİ}

Araştırma Makalesi

Sorumlu Yazar: Bihter Çolak ESETLİLİ, E-posta: bihtercolak@gmail.com, Tel: +90 (232) 3111515

Geliş Tarihi: 24 Ağustos 2013, Düzeltmelerin Gelişi: 24 Şubat 2014, Kabul: 02 Mart 2014

\section{ÖZET}

Türkiye'deki satış noktalarından alınan tıbbi bitkilerin çoğu doğadan toplama yoluyla sağlanmaktadır. Bu nedenle bitkilerin gelişim ve büyümesi kontrol altına alınamamaktadır. Özellikle çevresel kirliliğin tıbbi bitkilerin ağır metal içeriği üzerine yapabileceği olası etkiler ile ilgili toplumsal farkındalık her geçen gün artmaktadır. Bu amaçla İzmir'de nüfusun yoğun olarak bulunduğu ilçelerdeki farklı satış noktalarından tıbbi ve aromatik bitkiler toplanmıștır. Bazı bitki besin elementi konsantrasyonu (N, P, K, Ca, Mg, Na, Fe, Mn, Cu, Zn, B ve Mo) ile toksik ağır metal (Co, Cd, Cr, Ni, Pb ve Al) içerikleri ölçülmüştür. Sonuçta tıbbi bitkilerin zengin mineral içeriğine sahip olduğu ancak bazı ağır metallerin kritik düzeylerin üzerinde bulunduğu saptanmıştır.

Anahtar Kelimeler: Tıbbi ve aromatik bitkiler; Ağır metal; Temel besin elementleri; Makro besin elementleri; Mikro besin elementleri 


\section{Introduction}

Plants have been used for curing humans and protecting them from diseases throughout the history. In the Far East countries, some plants are commonly practiced for medical purposes (Polat \& Satıl 2012), treating diseases. In recent years, their use has increased also in the Western countries. In the early $20^{\text {th }}$ century, more than $40 \%$ of drugs were of plant origin, while the use of plant materials reduced to below 5\% in the mid 1970's (Craker \& Gardner 2005). On the other hand, with the increase in consumer awareness about health in 1980 's-1990's, demand for organic and naturally grown medicinal and aromatic plants increased as well.

In 2000's, conservation of genetic variety and standardisation of essential oils of the medicinal and aromatic plants gained utmost importance. For this purpose, primarily the developed countries started to reconsider and passed effective laws and regulations about herbal drugs (Baser et al 1986). In countries such as Germany, France, Switzerland and Italy, where alternative treatment methods draw attention and are even officially approved, necessary measures are taken based on scientific findings of both treatment and drug use in order to minimize the probable problems to be caused by these products. In Turkey, evaluations in relation to preparation and marketing of plant products are carried out by the regulations of the Ministry of Health and the Ministry of Food, Agriculture and Livestock.

Turkey has a rich flora containing over 10.000 plant varieties. Aromatic plants account for about $1 / 3$ of this flora and 3.000 of the varieties are endemic. Today, there are around 300 plant varieties sold in herbalists and 70 to 100 of them are exported (Baser 1997). Primarily thyme, bay leaf and cumin followed by sage, anise, locust, fennel, sumac and rosemary are among the most important export products.

The number of studies investigating the effects of environmental pollution on foods and medicinal plants due to advancing technology and examining the possible heavy metal accumulation has increased in the recent years. That's why these studies are closely related to human and environmental health (Kilınc \& Kutbay 2004). Consumption of medicinal and aromatic plants is low compared to other food products; however, they could be dangerous due to possibly high heavy metal contents and improper use of them. For this reason, it is important to form a database for the mineral compositions of medicinal and aromatic plants commonly used in Turkey towards establishing verbal standardisation.

The objective of this study was to determine the heavy metal and plant nutrient contents (chemical composition) of 18 different medicinal and aromatic plants consumed as spices or used in traditional disease treatment. The plant samples were obtained from different herbalists and shops in highly populated districts of Izmir province.

\section{Material and Methods}

\subsection{Materials}

Total of 18 different medicinal plants were sampled from urban herbalists and/or selling points in 25 districts of Izmir with differing population in September-October 2012. The names, scientific names and commonly known labels of plant samples are shown in Table 1. Plant parts were separated in accordance with the purpose of usage and analysed for their chemical composition including heavy metals and minerals/essential plant nutrients.

\subsection{Method}

Plant samples were brought to laboratory and dried at $60-65^{\circ} \mathrm{C}$ until the constant weight. From each sample, $5 \mathrm{~g}$ was weighed and ashed in a muffle furnace at $500{ }^{\circ} \mathrm{C}$. The ash was then solubilized with 1:1 $\mathrm{HCl}$ solution and diluted (Kacar \& Inal 2010; Ergün et al 2012). Nitrogen analysis was performed by Kjeldahl method (Kacar 1972). Plant nutrient elements and heavy metal concentrations were 
determined with ICP-AES (Kacar \& Inal 2010). The trade and model along with the operation conditions of the ICP-AES were given as the following: Device: ICP-AES (Varian 1.2-1.3 kw for axial); Plasma gas flow rate (Ar): $15 \mathrm{~L} \mathrm{~min}^{-1}$ (axial); Auxiliary gas flow rate (Ar): $1.5 \mathrm{~L} \mathrm{~min}^{-1}$; Reading time; 45-60 sec.

\section{Results and Discussion}

The concentrations of essential plant nutrients $(\mathrm{N}$, $\mathrm{P}, \mathrm{K}, \mathrm{Ca}, \mathrm{Mg}, \mathrm{Na}, \mathrm{Fe}, \mathrm{Mn}, \mathrm{Cu}, \mathrm{Zn}, \mathrm{B}$, and $\mathrm{Mo}$ ) and toxic heavy metals $(\mathrm{Co}, \mathrm{Cd}, \mathrm{Cr}, \mathrm{Ni}$, and $\mathrm{Pb})$ and $\mathrm{Al}$ of the 18 plant species under investigation are presented in Tables 2, 3 and 4, respectively. The essential primary plant nutrients are important for plant production and are vital for growth and development of all living bodies. Plants like nettle, parsley, dill and hibiscus, of which green parts can be freshly consumed, contain higher amounts of $\mathrm{N}, \mathrm{P}, \mathrm{K}, \mathrm{Ca}$ and $\mathrm{Mg}$ compared to other elements (Table 2). Nitrogen (4.80\%) and $\mathrm{Ca}(1.67 \%)$ concentrations of dill were found to be higher than those of other plants. Phosphorous content of sesame $(0.93 \%)$ and $\mathrm{K}$ of parsley $(1.65 \%)$ were found highest among the studied plants. Potassium, $\mathrm{P}, \mathrm{Ca}$ and $\mathrm{Mg}$ concentrations determined in the current study are compatible with the findings of Ozcan (2004) and Ergün et al (2012) on different medicinal plants. Daily intake of mineral elements ( $\mathrm{N}, \mathrm{Ca}, \mathrm{P}, \mathrm{Mg}$ and $\mathrm{K}$ ) by a person should be adjusted to $1 \%$ of body weight or less than $10 \mathrm{mg}$ (Imelouane et al 2011). WHO (2012) reports that daily intake of $\mathrm{K}$ should be at least $3510 \mathrm{mg} \mathrm{day}^{-1}$ for the regulation of blood pressure and minimisation of cardiovascular risks and cardiac diseases. Equal amounts of $\mathrm{Ca}$ and $\mathrm{P}$ are recommended for $\mathrm{P}$ and $\mathrm{Ca}$ nutrition of an adult. For 1-10 year old children, $800 \mathrm{mg}$ of $\mathrm{P}$ is recommended and for 11-24 years of age $1200 \mathrm{mg}$ (Samur 2008). The daily intake of $\mathrm{Mg}$ is recommended to be $300-420 \mathrm{mg}$ in adults (Vormann 2003).

With respect to secondary plant nutrients, Fe content of basil (689 $\left.\mathrm{mg} \mathrm{kg}^{-1}\right)$, Mn of galanga (315 $\left.\mathrm{mg} \mathrm{kg}{ }^{-1}\right)$, Zn of black cumin $\left(79 \mathrm{mg} \mathrm{kg}^{-1}\right)$ and $\mathrm{Cu}$ of basil (19.3 mg kg-1) were found higher (Table 3 ) than the other plants in this study. Critical limit values for $\mathrm{Cu}$ and $\mathrm{Zn}$ are not given in the reports of WHO (2004). Therefore, critical concentrations could be different for perennial and annual plants. Copper concentration of plants is reported to range between 16-20 mg kg-1 in general (Mengel \& Kirkby 2004). On the other hand, Bowen (1966) and Allaway (1968) stated that agricultural products could contain 4-15 mg kg-1 $\mathrm{Cu}$ and 15-200 mg kg-1 $\mathrm{Zn}$. The $\mathrm{Zn}$ concentrations of the plants reported in this study are compatible with the values in literature, whereas $\mathrm{Cu}$ concentrations are higher for basil, cumin and coriander. Copper is a vital element for plants, animals and humans, but its excess intake might cause health problems. $2.5 \mathrm{mg}$ of daily $\mathrm{Cu}$ intake can meet the daily requirement of adults. On the other hand, Zn, an essential element for nearly all living cells, is recommended to be consumed at the amount of $15 \mathrm{mg}$ a day (Samur 2008; Ulger \& Coskun 2003). In a study investigating the mineral constituents of edible wild plants, it is reported that Mn might be high in certain plants like hibiscus $\left(56.0 \mathrm{mg} \mathrm{kg}^{-1}\right)$ and basil (65.1 $\mathrm{mg} \mathrm{kg}^{-1}$ ) (Chizzola et al 2003; Turan et al 2003). In the current study, it is noteworthy that Mn content is much higher in some plants than the values in literature. The recommended daily intake of $\mathrm{Mn}$ is $4.50 \mathrm{mg}$ for humans. Considering the $\mathrm{Fe}$ contents of plants, most plants were determined to contain much higher concentration of $\mathrm{Fe}$ compared to $100-300 \mathrm{mg} \mathrm{kg}^{-1}$ interval reported by Reuter and Robinson (1986) for higher plants. Due to cereal-based nutritional habits in Turkey, the recommended daily intake of $\mathrm{Fe}$, the most important functional component of human blood, is $10 \mathrm{mg}$ for an adult male, $15-18 \mathrm{mg}$ for females and 27-30 mg for pregnant women (Samur 2008). In addition, the intake of essential secondary plant nutrients / trace elements ( $\mathrm{Zn}, \mathrm{Fe}, \mathrm{Mn}, \mathrm{Cu}, \mathrm{Cr}$ and $\mathrm{Ni}$ ) is recommended not to exceed $0.01 \%$ of body weight (Imelouane 2011). 
Table 1- Medicinal and aromatic plants, their; names, studied-parts and medical effects

Çizelge 1- Çalışma kapsamındaki tıbbi ve aromatik bitkilerin Latince isimleri, çalışılan parçaları ve tıbbi amaçlı kullanım özellikleri

\begin{tabular}{|c|c|c|c|c|}
\hline Plant & Botanical name & Parts studied & Medical effects & References \\
\hline Nettle & Urtica dioica L. & Leaf & $\begin{array}{l}\text { Diuretic, astringent, antiallergenic, } \\
\text { prostate treatment, hemorrhoids, } \\
\text { baldness }\end{array}$ & $\begin{array}{l}\text { Polat \& Sat1l 2012; Cakilcioglu et al } \\
\text { 2011; Akgünlü 2012; Polat et al } 2013\end{array}$ \\
\hline Mint & Mentha piperita L. & Leaf & $\begin{array}{l}\text { Gas expectorant, antispasmodic, bile } \\
\text { regulatory, antiseptic, cold, flu }\end{array}$ & $\begin{array}{l}\text { Polat \& Satıl 2012; Cakilcioglu et al } \\
\text { 2011; Saganuwan 2010; Akgünlü } 2012\end{array}$ \\
\hline Thyme & Thymus vulgaris L. & Leaf & $\begin{array}{l}\text { Gas expectorant, antitussive, antisep- } \\
\text { tic, antispasmodic, cold, flu }\end{array}$ & $\begin{array}{l}\text { Polat \& Satıl 2012; Cakilcioglu et al } \\
\text { 2011; Saganuwan } 2010\end{array}$ \\
\hline $\begin{array}{l}\text { Rose- } \\
\text { mary }\end{array}$ & Rosmarinus officinalis L. & Leaf & $\begin{array}{l}\text { Antimicrobial, antifungal, antioxi- } \\
\text { dant, antiseptic }\end{array}$ & Saganuwan 2010; Polat \& Sat1l 2012 \\
\hline Basil & Ocimum basilicum L. & Leaf & $\begin{array}{l}\text { Antioxidant, cardioprotective, anti- } \\
\text { spasmodic, antidiabetic, antimicrobi- } \\
\text { al, antifungal, antioxidant, antiseptic, } \\
\text { analgesic }\end{array}$ & $\begin{array}{l}\text { Polat \& Satil 2012; Zeybek \& Haksel } \\
2010\end{array}$ \\
\hline Dill & Anethum graveolens L. & Leaf & $\begin{array}{l}\text { Antispasmodic, analgesic, digestive } \\
\text { problems, antioxidants, antimicrobial }\end{array}$ & $\begin{array}{l}\text { Elik 2010; Zeybek \& Haksel 2010; } \\
\text { Faydaoglu \& Surucuoglu } 2011\end{array}$ \\
\hline Malva & Malva sylvestris L. & Leaf & $\begin{array}{l}\text { Anti-inflammatory, colitis and mouth } \\
\text { infections, chronic bronchitis, ab- } \\
\text { scesses, haemorrhoids, laxatives, } \\
\text { abdominal pain }\end{array}$ & $\begin{array}{l}\text { Polat \& Satıl 2012; Cakilcioglu et al } \\
\text { 2011; Akgünlü 2012; Polat et al } 2013\end{array}$ \\
\hline Parsley & Petroselinum crispum L. & Leaf & $\begin{array}{l}\text { Antimicrobial, hypotensive, diuretic, } \\
\text { laxative, spasmodic }\end{array}$ & Polat \& Sat11 2012; Saganuwan 2010 \\
\hline Ginger & Zingiber officinale L. & Root & $\begin{array}{l}\text { Nausea, antioxidant, antithrombotic, } \\
\text { anticarcinogen, antioxidant, anti- } \\
\text { migraine and antilipidemic }\end{array}$ & $\begin{array}{l}\text { Saganuwan 2010; Faydaoglu \& } \\
\text { Surucuoglu 2011; Zeybek \& Haksel } \\
2010\end{array}$ \\
\hline Turmeric & Curcuma longa L. & Root & $\begin{array}{l}\text { Antioxidant, anti-inflammatory and } \\
\text { anticarcinogen }\end{array}$ & $\begin{array}{l}\text { Faydaoglu \& Surucuoglu 2011; } \\
\text { Zeybek \& Haksel } 2010\end{array}$ \\
\hline Galangal & Alpinia officinarum L. & Root & $\begin{array}{l}\text { Anti-inflammatory, } \\
\text { antitumour,anticarcinogen, antimuta- } \\
\text { genic, antimicrobial /antiviral }\end{array}$ & $\begin{array}{l}\text { Faydaoglu \& Surucuoglu 2011; } \\
\text { Zeybek \& Haksel } 2010\end{array}$ \\
\hline $\begin{array}{l}\text { Cinna- } \\
\text { mon }\end{array}$ & $\begin{array}{l}\text { Cinnamomum aromati- } \\
\text { cum L. }\end{array}$ & $\begin{array}{l}\text { Stem and } \\
\text { branch }\end{array}$ & $\begin{array}{l}\text { Anti-inflammatory, antitumour, } \\
\text { anticarcinogen, antimutagenic, anti- } \\
\text { microbial / antiviral }\end{array}$ & $\begin{array}{l}\text { Saganuwan 2010; Zeybek \& Haksel } \\
2010\end{array}$ \\
\hline Cumin & Cuminum cyminum L. & Fruit & $\begin{array}{l}\text { Antibacterial, antifungal, anti-inflam- } \\
\text { matory, antioxidant, astringent }\end{array}$ & $\begin{array}{l}\text { Faydaoglu \& Surucuoglu 2011; } \\
\text { Zeybek \& Haksel } 2010\end{array}$ \\
\hline $\begin{array}{l}\text { Black } \\
\text { cumin }\end{array}$ & Nigella sativa L. & Fruit & $\begin{array}{l}\text { Anti-inflammatory, antitumour, } \\
\text { anticarcinogen, antimicrobial / anti- } \\
\text { viral, antitumour, colitis, peritonitis, } \\
\text { arthritis, oedema }\end{array}$ & $\begin{array}{l}\text { Saganuwan 2010; Zeybek \& Haksel } \\
2010\end{array}$ \\
\hline $\begin{array}{l}\text { Corian- } \\
\text { der }\end{array}$ & Coriandrum sativum L. & Fruit & $\begin{array}{l}\text { antimicrobial / antiviral, antiulcer, } \\
\text { regulation of blood pressure, anti- } \\
\text { inflammatory }\end{array}$ & $\begin{array}{l}\text { Saganuwan 2010; Faydaoglu \& } \\
\text { Surucuoglu } 2011\end{array}$ \\
\hline Fennel & Foeniculum vulgare L. & Fruit & $\begin{array}{l}\text { Diuretic, anaemia, digestive system } \\
\text { diseases }\end{array}$ & Polat \& Sat1l 2012; Saganuwan 2010 \\
\hline Sumac & Rhus coriaria L. & Fruit & $\begin{array}{l}\text { Antibacterial, antifungal, Antidiaretic } \\
\text { digestive, hemorrhoids, rheumatism }\end{array}$ & $\begin{array}{l}\text { Cakilcioglu et al 2011; Saganuwan } \\
\text { 2010; Faydaoglu \& Surucuoglu } 2011\end{array}$ \\
\hline Sesame & Sesamum indicum L. & Seed & $\begin{array}{l}\text { Laxatives, anti-diabetic, anti-oxidant, } \\
\text { tranquilisers, digestive system dis- } \\
\text { eases }\end{array}$ & Saganuwan 2010 \\
\hline
\end{tabular}


Table 2- The concentrations of primary nutrients in the investigeted plants/spices Çizelge 2- Tıbbi ve aromatik bitkilerin makro element içeriği

\begin{tabular}{|c|c|c|c|c|c|}
\hline \multirow{2}{*}{ Plants/Spices } & \multicolumn{5}{|c|}{ Nutrient elements (\%) } \\
\hline & $N$ & $P$ & $K$ & $\mathrm{Ca}$ & $M g$ \\
\hline Cinnamon & $0.57^{\mathrm{a}} \pm 0.02^{\mathrm{b}}$ & $0.07 \pm 0.07$ & $0.60 \pm 0.09$ & $1.11 \pm 0.02$ & $0.06 \pm 0.003$ \\
\hline Thyme & $1.57 \pm 0.04$ & $0.30 \pm 0.05$ & $0.84 \pm 0.09$ & $1.15 \pm 0.03$ & $0.15 \pm 0.003$ \\
\hline Cumin & $2.54 \pm 0.04$ & $0.48 \pm 0.02$ & $1.02 \pm 0.01$ & $1.03 \pm 0.01$ & $0.17 \pm 0.001$ \\
\hline Nettle & $3.61 \pm 0.10$ & $0.50 \pm 0.05$ & $1.08 \pm 0.04$ & $1.15 \pm 0.01$ & $0.10 \pm 0.002$ \\
\hline Ginger & $1.65 \pm 0.05$ & $0.27 \pm 0.01$ & $1.03 \pm 0.01$ & $0.30 \pm 0.09$ & $0.16 \pm 0.001$ \\
\hline Dill & $4.80 \pm 0.14$ & $0.52 \pm 0.03$ & $1.58 \pm 0.11$ & $1.67 \pm 0.10$ & $0.26 \pm 0.001$ \\
\hline Sumac & $0.71 \pm 0.02$ & $0.17 \pm 0.01$ & $0.70 \pm 0.03$ & $0.37 \pm 0.03$ & $0.09 \pm 0.005$ \\
\hline Malva & $2.50 \pm 0.11$ & $0.53 \pm 0.03$ & $1.04 \pm 0.05$ & $1.19 \pm 0.01$ & $0.17 \pm 0.002$ \\
\hline Parsley & $3.31 \pm 0.04$ & $0.55 \pm 0.03$ & $1.65 \pm 0.10$ & $1.54 \pm 0.13$ & $0.26 \pm 0.010$ \\
\hline Turmeric & $1.41 \pm 0.03$ & $0.37 \pm 0.01$ & $1.05 \pm 0.01$ & $0.18 \pm 0.01$ & $0.17 \pm 0.003$ \\
\hline Galanga & $0.87 \pm 0.05$ & $0.23 \pm 0.03$ & $1.03 \pm 0.01$ & $0.23 \pm 0.04$ & $0.17 \pm 0.005$ \\
\hline Mint & $2.90 \pm 0.02$ & $0.41 \pm 0.04$ & $1.16 \pm 0.07$ & $1.25 \pm 0.04$ & $0.21 \pm 0.010$ \\
\hline Sesame & $4.14 \pm 0.03$ & $0.93 \pm 0.06$ & $0.62 \pm 0.02$ & $0.13 \pm 0.02$ & $0.24 \pm 0.020$ \\
\hline Fennel & $2.61 \pm 0.03$ & $0.66 \pm 0.05$ & $1.06 \pm 0.01$ & $1.00 \pm 0.05$ & $0.26 \pm 0.020$ \\
\hline Basil & $3.44 \pm 0.03$ & $0.46 \pm 0.01$ & $1.05 \pm 0.01$ & $1.18 \pm 0.05$ & $0.19 \pm 0.004$ \\
\hline Black Cumin & $3.54 \pm 0.04$ & $0.84 \pm 0.01$ & $0.82 \pm 0.05$ & $0.73 \pm 0.02$ & $0.15 \pm 0.005$ \\
\hline Coriander & $2.30 \pm 0.05$ & $0.76 \pm 0.02$ & $0.99 \pm 0.02$ & $0.83 \pm 0.03$ & $0.17 \pm 0.003$ \\
\hline Rosemary & $0.90 \pm 0.06$ & $0.17 \pm 0.04$ & $1.02 \pm 0.01$ & $1.20 \pm 0.01$ & $0.15 \pm 0.004$ \\
\hline
\end{tabular}

a, mean; b, standard deviation

Boron content of nettle $\left(67.3 \mathrm{mg} \mathrm{kg}^{-1}\right)$ and Mo content of parsley $\left(5.73 \mathrm{mg} \mathrm{kg}^{-1}\right)$ were found higher than other plants (Table 3). Many foods and especially plant products are rich in B and therefore, no limit value could be set for dietary intake of $\mathrm{B}$ for the human. World Health Organization (WHO) states that a healthy adult can take 1-13 mg of B in daily diet (Demirtas 2010). The most suitable and healthy daily intake of B is $1.5 \mathrm{mg}$ for children, $2 \mathrm{mg}$ for teenager males, $2 \mathrm{mg}$ for females and $3 \mathrm{mg}$ for females before menopause, $2.5 \mathrm{mg}$ for pregnant women and $2.5 \mathrm{mg}$ for breastfeeding mothers (Demirtas 2010). Molybdenum concentrations of plants changes by seasons as well as the Mo concentration and $\mathrm{pH}$ of the soil. Molybdenum concentrations can be $0.5-100$ $\mathrm{mg} \mathrm{kg}{ }^{-1}$ in dry matter of plants grown in Mo rich soils. WHO (1993) recommends $0.1-0.3 \mathrm{mg}$ of daily Mo intake for adults.

The results of heavy metal analyses indicated that $\mathrm{Al}$ concentration of rosemary $\left(2087 \mathrm{mg} \mathrm{kg}^{-1}\right)$, Co of galanga $\left(1.35 \mathrm{mg} \mathrm{kg}^{-1}\right), \mathrm{Cr}$ of cumin $(1.36$ $\left.\mathrm{mg} \mathrm{kg}{ }^{-1}\right), \mathrm{Cd}$ of thyme $\left(0.26 \mathrm{mg} \mathrm{kg}^{-1}\right)$, Ni of mint $\left(4.39 \mathrm{mg} \mathrm{kg}^{-1}\right)$ and $\mathrm{Pb}$ of malva $\left(1.69 \mathrm{mg} \mathrm{kg}^{-1}\right)$ are higher than those of the other plants. Daghan et al (2013) stated that the critical Ni concentrations for susceptible plants is $>10 \mathrm{mg} \mathrm{kg}^{-1}$ and for slightly tolerant plants is $>50 \mathrm{mg} \mathrm{kg}^{-1}$. The Ni findings in the current study are lower than the specified reports of the same author.

The concentrations of $\mathrm{Pb}$ and $\mathrm{Cd}$ reported by WHO (1999) for medicinal and aromatic plants 
Table 3- The concentrations of secondary nutrients in the investigated plants/spices

Çizelge 3- Tibbi ve aromatik bitkilerin mikro element içeriği

\begin{tabular}{|c|c|c|c|c|c|c|}
\hline \multirow{2}{*}{ Spices } & \multicolumn{6}{|c|}{ Elements $\left(m g \mathrm{~kg}^{-1}\right)$} \\
\hline & $\mathrm{Fe}$ & $M n$ & $Z n$ & $C u$ & $B$ & Mo \\
\hline Cinnamon & $59^{a} \pm 9^{b}$ & $193 \pm 4$ & $14 \pm 0.71$ & $1.8 \pm 0.20$ & $12.8 \pm 0.31$ & $0.41 \pm 0.26$ \\
\hline Thyme & $221 \pm 21$ & $50 \pm 5$ & $28 \pm 2.43$ & $8.2 \pm 0.77$ & $32.6 \pm 1.72$ & $0.56 \pm 0.07$ \\
\hline Cumin & $579 \pm 99$ & $51 \pm 7$ & $38 \pm 1.49$ & $3.8 \pm 0.31$ & $23.6 \pm 2.14$ & $0.39 \pm 0.05$ \\
\hline Nettle & $237 \pm 15$ & $65 \pm 6$ & $31 \pm 2.34$ & $8.7 \pm 0.25$ & $67.3 \pm 5.19$ & $0.44 \pm 0.09$ \\
\hline Ginger & $321 \pm 20$ & $227 \pm 11$ & $30 \pm 1.61$ & $6.4 \pm 0.55$ & $7.3 \pm 0.35$ & $0.52 \pm 0.06$ \\
\hline Dill & $214 \pm 7$ & $86 \pm 5$ & $48 \pm 2.90$ & $9.7 \pm 0.74$ & $39.0 \pm 2.27$ & $0.90 \pm 0.09$ \\
\hline Sumac & $132 \pm 25$ & $7 \pm 1$ & $12 \pm 0.92$ & $4.1 \pm 0.29$ & $11.5 \pm 0.66$ & $0.15 \pm 0.01$ \\
\hline Malva & $253 \pm 37$ & $45 \pm 2$ & $49 \pm 1.86$ & $8.9 \pm 0.70$ & $39.7 \pm 3.30$ & $0.96 \pm 0.28$ \\
\hline Parsley & $242 \pm 24$ & $110 \pm 11$ & $70 \pm 5.65$ & $10.4 \pm 0.56$ & $55.0 \pm 6.38$ & $5.73 \pm 2.82$ \\
\hline Turmeric & $294 \pm 15$ & $59 \pm 9$ & $16 \pm 1.68$ & $3.3 \pm 0.26$ & $5.4 \pm 0.07$ & $0.90 \pm 0.02$ \\
\hline Galanga & $502 \pm 40$ & $315 \pm 16$ & $33 \pm 2.78$ & $3.8 \pm 0.29$ & $6.2 \pm 0.30$ & $0.24 \pm 0.08$ \\
\hline Mint & $543 \pm 54$ & $122 \pm 3$ & $33 \pm 1.67$ & $9.3 \pm 0.87$ & $41.4 \pm 1.30$ & $0.44 \pm 0.08$ \\
\hline Sesame & $83 \pm 3$ & $24 \pm 1$ & $76 \pm 1.01$ & $2.4 \pm 0.38$ & $12.9 \pm 0.09$ & $1.76 \pm 0.35$ \\
\hline Fennel & $103 \pm 14$ & $42 \pm 3$ & $44 \pm 1.18$ & $12.5 \pm 0.94$ & $36.1 \pm 2.20$ & $0.12 \pm 0.02$ \\
\hline Basil & $689 \pm 17$ & $90 \pm 2$ & $53 \pm 0.90$ & $19.3 \pm 0.60$ & $39.9 \pm 0.98$ & $0.82 \pm 0.03$ \\
\hline Black Cumin & $107 \pm 5$ & $32 \pm 1$ & $79 \pm 1.36$ & $13.9 \pm 1.39$ & $37.9 \pm 1.75$ & $0.21 \pm 0.02$ \\
\hline Coriander & $197 \pm 51$ & $47 \pm 5$ & $57 \pm 2.49$ & $18.6 \pm 3.95$ & $30.0 \pm 1.51$ & $0.36 \pm 0.05$ \\
\hline Rosemary & $338 \pm 25$ & $49 \pm 3$ & $28 \pm 2.65$ & $7.0 \pm 0.65$ & $44.5 \pm 1.80$ & $0.40 \pm 0.03$ \\
\hline
\end{tabular}

a, mean; b, standard deviation

are 10 and $0.3 \mathrm{mg} \mathrm{kg}^{-1}$, respectively. In our study, $\mathrm{Pb}$ and $\mathrm{Cd}$ concentrations were found to be much lower than these values (Table 4). Previous studies have established that medicinal and aromatic plants can contain some toxic heavy metals like $\mathrm{Cd}$, As, $\mathrm{Pb}$ and $\mathrm{Hg}$ (Obiajunwa et al 2002; Olukayode Ajasa et al 2004). Hina et al (2011) analysed heavy metal concentrations of 7 different medicinal plants taken from public markets in Karachi and reported the highest Cd concentration for Onosma bracteatum (4.91 mg kg-1) and fennel (4.89 $\mathrm{mg} \mathrm{kg}^{-1}$ ) samples. In another study carried out by Dwivedi \& Dey (2002), $\mathrm{Pb}$ and $\mathrm{Cd}$ concentrations were determined to change between $2.62-32.76 \mathrm{mg} \mathrm{kg}^{-1}$ and $0.002-$ $0.056 \mathrm{mg} \mathrm{kg}^{-1}$, respectively, in the heavy metal analysis conducted on 28 different commonly used medicinal plants.

It is known that $\mathrm{Al}$ concentration is higher in plants than in animal feed and the $\mathrm{Al}$ content of plants differ due to the soil and atmospheric conditions. In different studies, daily Al intake of humans is predicted to be $1.53-160 \mathrm{mg}$ (Sorensen et al 1974). Chromium concentration of wheat flour was reported to be $5-10 \mu \mathrm{g} \mathrm{kg}^{-1}$ (Anderson et al 1992) and in some spices like black pepper it could present at higher concentrations than those of the other foods (Akgünlü 2012). Daily dietary $\mathrm{Cr}$ intake of human is recommended as $60 \mu \mathrm{g}$ by WHO (Krejpcio 2001). With respect to Co which is an element found in the structure of B12 vitamin, 
Table 4- Heavy metal concentrations of the investigeted spices

Çizelge 4- Tibbi ve aromatik bitkilerin ă̆ır metal içeriği

\begin{tabular}{|c|c|c|c|c|c|c|}
\hline \multirow{2}{*}{ Spices } & \multicolumn{6}{|c|}{ Elements $\left(\mathrm{mg} \mathrm{kg}^{-1}\right)$} \\
\hline & $A l$ & $\mathrm{Co}$ & $N i$ & $\mathrm{~Pb}$ & $C d$ & $\mathrm{Cr}$ \\
\hline Cinnamon & $402^{\mathrm{a}} \pm 52^{\mathrm{b}}$ & $0.05 \pm 0.002$ & $0.14 \pm 0.01$ & $0.28 \pm 0.04$ & $0.16 \pm 0.01$ & $0.10 \pm 0.01$ \\
\hline Thyme & $810 \pm 72$ & $0.20 \pm 0.02$ & $3.52 \pm 0.31$ & $0.48 \pm 0.09$ & $0.26 \pm 0.04$ & $0.42 \pm 0.05$ \\
\hline Cumin & $1020 \pm 66$ & $0.30 \pm 0.03$ & $3.39 \pm 0.25$ & $0.42 \pm 0.05$ & $0.05 \pm 0.005$ & $1.36 \pm 0.16$ \\
\hline Nettle & $730 \pm 41$ & $0.17 \pm 0.02$ & $1.96 \pm 0.27$ & $0.49 \pm 0.07$ & $0.03 \pm 0.003$ & $0.93 \pm 0.13$ \\
\hline Ginger & $1215 \pm 57$ & $0.23 \pm 0.02$ & $1.32 \pm 0.05$ & $1.67 \pm 0.05$ & $0.05 \pm 0.02$ & $0.56 \pm 0.06$ \\
\hline Dill & $496 \pm 42$ & $0.23 \pm 0.03$ & $2.02 \pm 0.18$ & $0.81 \pm 0.09$ & $0.13 \pm 0.04$ & $0.70 \pm 0.10$ \\
\hline Sumac & $358 \pm 49$ & $0.08 \pm 0.01$ & $1.41 \pm 0.13$ & $0.73 \pm 0.10$ & $0.02 \pm 0.003$ & $0.85 \pm 0.17$ \\
\hline Malva & $578 \pm 46$ & $0.18 \pm 0.02$ & $1.45 \pm 0.19$ & $1.69 \pm 0.24$ & $0.08 \pm 0.01$ & $0.96 \pm 0.16$ \\
\hline Parsley & $267 \pm 52$ & $0.22 \pm 0.03$ & $4.26 \pm 0.64$ & $1.14 \pm 0.09$ & $0.12 \pm 0.04$ & $0.61 \pm 0.06$ \\
\hline Turmeric & $263 \pm 8$ & $0.24 \pm 0.02$ & $0.64 \pm 0.04$ & $0.33 \pm 0.07$ & $0.03 \pm 0.02$ & $0.55 \pm 0.04$ \\
\hline Galanga & $483 \pm 11$ & $1.35 \pm 0.12$ & $2.80 \pm 0.21$ & $0.86 \pm 0.07$ & $0.03 \pm 0.02$ & $1.28 \pm 0.24$ \\
\hline Mint & $345 \pm 12$ & $0.61 \pm 0.05$ & $4.39 \pm 0.65$ & $0.85 \pm 0.13$ & $0.04 \pm 0.02$ & $1.17 \pm 0.16$ \\
\hline Sesame & $3 \pm 1$ & $0.17 \pm 0.01$ & $0.46 \pm 0.03$ & $0.17 \pm 0.01$ & $0.04 \pm 0.003$ & $0.18 \pm 0.005$ \\
\hline Fennel & $21 \pm 7$ & $0.21 \pm 0.02$ & $3.53 \pm 0.19$ & $0.31 \pm 0.06$ & $0.03 \pm 0.002$ & $0.44 \pm 0.02$ \\
\hline Basil & $574 \pm 182$ & $0.48 \pm 0.01$ & $0.90 \pm 0.02$ & $0.91 \pm 0.09$ & $0.04 \pm 0.003$ & $0.74 \pm 0.02$ \\
\hline Black Cumin & $330 \pm 29$ & $0.08 \pm 0.01$ & $4.25 \pm 0.43$ & $0.23 \pm 0.02$ & $0.07 \pm 0.005$ & $0.22 \pm 0.02$ \\
\hline Coriander & $427 \pm 94$ & $0.18 \pm 0.02$ & $3.29 \pm 0.33$ & $0.23 \pm 0.03$ & $0.07 \pm 0.007$ & $0.38 \pm 0.05$ \\
\hline Rosemary & $2087 \pm 100$ & $0.16 \pm 0.01$ & $1.81 \pm 0.10$ & $1.19 \pm 0.11$ & $0.03 \pm 0.002$ & $0.72 \pm 0.07$ \\
\hline
\end{tabular}

WHO (2006) recommends $0.1 \mu \mathrm{g}$ of daily intake through $2.4 \mu \mathrm{g} \mathrm{B} 12$ vitamin. In a recent study, only trace amounts of $\mathrm{Ni}, \mathrm{Al}, \mathrm{Cr}$ and $\mathrm{Co}$ have been found necessary for all living beings, except for other heavy metals (Imelouane 2011).

\section{Conclusions}

It is concluded that it is important to analyse the chemical compositions of medicinal and aromatic plants, commonly used as spices and traditional health aids, in order to assure their safety. The medicinal plants investigated in the current study, which has well known positive effects on human health are determined to be rich in minerals. However, it is noteworthy that some heavy metals such as
$\mathrm{Pb}, \mathrm{Cd}, \mathrm{Cr}$ could be harmful to health according to international references, were measured above the reported critical levels. Therefore, if possible, controlling the growth conditions of medicinal plants, unless otherwise constantly monitoring the market, are recommended for health friendly supply of medicinal and aromatic plants.

\section{References}

Akgünlü S B (2012). Mineral content and microbiological analysis of some wild edible vegetables consumed in Kilis and Gaziantep Provinces. MSc. Thesis (unpublished), Kilis 7 Aralık University

Ajasa M O, Bello M O, Ibrahim A O, Ogunwande I A \& Olawore N O (2004). Heavy trace metals and 
macronutrients status in herbal plants of Nigeria. Food Chemistry 85: 67-71

Allaway W H (1968). Agronomic controls over the environment cycling of trace elements, Advances in Agronomy 49: 55-118

Anderson R A, Bryden N A \& Polansky M M (1992). Dietary Chromium Intake. Freely chosen diets, institutional diets and individual foods. Biological Trace Element Research 32: 117

Baser K H C (1997). Use of drugs and alcohol industries of medicinal and aromatic plants. Istanbul Chamber of Commerce, Publication No: 1997-39, Istanbul

Baser K H C, Honda G \& Miki W (1986). Herb drugs and herbalists in Turkey. Institute for the Study of Languages and Cultures of Asia and Africa, Tokyo

Bowen H J M (1966). Trace Elements in Biochemistry. Academic press, London and New York

Cakilcioglu U, Khatun S, Turkoglu I \& Hayta S (2011). Ethnopharmacological survey of medicinal plants in Maden (Elazig-Turkey). Journal of Ethnopharmacology 137: 469-486

Chizzola R, Michitsch H \& Franz C (2003). Monitoring of Metallic Micronutrients and Heavy Metals in Herbs, Spices and Medicinal Plants from Austria. European Food Research and Technology 216: 407-411

Craker L E \& Gardner Z (2005). Sustaining the harvest: Challenges in MAP production and markets. Acta Horticulturae 676: 25-30

Dağhan H, Uygur V, Köleli N, Arslan M \& Eren A (2013). The effect of heavy metal treatments on uptake of nitrogen, phosphorus and potassium in transgenic and non-transgenic tobacco plants. Tarım Bilimleri Dergisi 19: 129-139

Demirtas A (2010). Significance of boron for human nutrition and health, Journal of Agricultural Faculty of Atatürk University 41(1): 75-80

Dwivedi S K, Dey S (2002). Medicinal herbs: A potential source of toxic metal exposure for man and animals in India. Arch. Environmental Health 57: 229-231

Sorenson J R J, Campbell I R, Tepper L B \& Lingg R $\mathrm{D}$ (1974). Aluminium in the environment and human health. Environmental Health Perspectives 8: 3-95

Elik H (2010). Effects of different sowing times on some agronomical and technological characteristics of dill (Anethum graveolens L.) in Diyarbakir ecological conditions. MSc Thesis, Cukurova University, Turkey
Ergün N, Yolcu H \& Özcubukcu S (2012). Heavy metal accumulation some medicinal plants on Amanos mountains. BIBAD 5 (1): 21-23

Faydaoglu E \& Surucuoglu M S (2011). History of the use of medical and aromatic plants and their economic importance. Kastamonu University, Journal of Forestry Faculty 11(1): 52 - 67

Hina B, Rizwani G H \& Naseem S (2011). Determination of toxic metals in some herbal drugs through atomic absorption spectroscopy. Pakistan Journal of Pharmaceutical Sciences 24(3): 353-358

Imelouane B, Tahri M, Elbastrioui M, Aouinti F \& Elbachiri A (2011). Mineral contents of some medicinal and aromatic plants growing in Eastern Morocco. Journal of Material Environmental Science 2(2): 104-111

Kacar B \& İnal A (2010). Plant Analysis. Nobel, Ankara

Kacar B (1972). Chemical Analysis of Plant and SoilII, Plant Analysis. Ankara University, Faculty of Agriculture, Ankara

Kilinc M \& Kutbay G (2004). Plant Ecology. Plame Publishing, Ankara

Krejpcio Z (2001). Essentiality of Chromium for Human Nutrition and Health. Polish Journal of Environmental Studies 10(6): 399-404

Mengel K \& Kirkby E A (2004). Principles of Plant Nutrition, Springer-Verlag, New York

Obiajunwa E I, Adebajo A C \& Omobuwajo O R (2002). Essential and trace element contents of some Nigerian medicinal plants. Journal of Radioanalytical Nuclear Chemistry 252(3): 473-476

Özcan M (2004). Mineral contents of some plants used as condiments in Turkey. Food Chemistry 84: 437-440

Polat R \& Sat1l F (2012). An ethnobotanical survey of medicinal plants in Edremit Gulf (Balıkesir - Turkey). Journal of Ethnopharmacology 139: 626-641

Polat R, Cakilcioglu U \& Sat1l F (2013). Traditional uses of medicinal plants in Solhan (Bingöl-Turkey). Journal of Ethnopharmacology 148: 951-963

Reuter D J \& Robinson J B (1986). Plant analysis: An interpretation manual. Inkata Press, Melbourne, Australia

Saganuwan A S (2010). Some medicinal plants of Arabian Pennisula. Journal of Medicinal Plants Research 4(9): 766-788

Samur G (2008). Vitamins, Minerals and Healthy. Ministry of Health, Klasmat Publishing, Ankara 
Turan M, Kordali S B, Zengin H, Dursun A \& Sezen Y (2003). Macro and micro mineral content of some wild edible leaves consumed in Eastern Anatolia. Soil and Plant Science 53: 129-137

Ulger H \& Coskun A (2003). Zinc: Basic functions and metabolism. Journal of the Faculty of Duzce Medicine 5(2): 38-44

Vormann J (2003). Magnesium: Nutrition and metabolism. Molecular Aspects Medicine 24(1-3): 27-37

WHO (1989). Toxicological evaluation of certain food additives and contaminants. WHO Food Additives Ser. No. 24. World Health Organisation, Geneva

WHO (1993). Evaluation of certain food additives and contaminants. 41st Report of the FAO/WHO (1993)
Expert Committee on Food Additives Technical Report Series. World Health Organization, Geneva, Switzerland

WHO (1999). WHO monographs on selected medicinal plants, vol.1 World Health Organization Geneva, Switzerland

WHO (2004). Monographs on selected medicinal plants. Volume 2. World Health Organisation

WHO (2012). Effect of increased potassium intake on cardiovascular disease, coronary heart disease and stroke. Geneva, World Health Organization (WHO)

Zeybek U \& Haksel M (2010). Important medicinal plants and their use in Turkey and around the world. Argefar and Helvacizade Medical Publications, Izmir 